\title{
Comparison of Risk Factors and Neonatal Outcomes in Early-Onset and Late-Onset Preeclampsia
}

\section{Erken ve Geç Başlangıçlı Preeklampside Risk Faktörleri ve Neonatal Sonuçların Karşıllaştırılması}

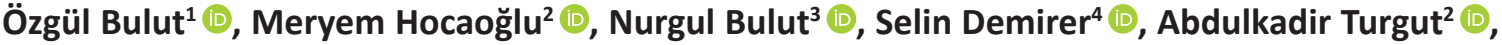 Fahri Ovalı ${ }^{1}$ (D)}

\begin{abstract}
${ }^{1}$ Istanbul Medeniyet University Goztepe Training and Research Hospital, Department of Pediatrics, Division of Neonatology, Istanbul, Turkey ${ }^{2}$ Istanbul Medeniyet University, Goztepe Training and Research Hospital Department of Obstetrics and Gynecology Clinic, Istanbul, Turkey ${ }^{3}$ Istanbul Medeniyet University Goztepe Training and Research Hospital, Department of Biostatistics and Medical Informatics, Istanbul, Turkey ${ }^{4}$ Istanbul University, Aziz Sancar Institute of Experimental Medicine, Department of Genetics, Istanbul, Turkey
\end{abstract}

ORCID ID: Ö.B. 0000-0001-9939-7375; M.H. 0000-0002-1832-9993; N.B. 0000-0002-7247-6302; S.D. 0000-0002-5888-0835; A.T. 0000-0002-3156-2116; F.O. 0000-0002-9717-313X

Citation/Atf: Bulut O, Hocaoglu M, Bulut N, Demirer S, Turgut A, Ovali F. Comparison of risk factors and neonatal outcomes in early-onset and late-onset preeclampsia. Çocuk Dergisi - Journal of Child 2020;20(3):100-106. https://doi.org/10.26650/jchild.2020.3.809801

\section{ABSTRACT}

Objective: To compare the maternal risk factors and early neonatal outcomes in early-onset and late-onset preeclampsia.

Material and Methods: In our hospital, patients diagnosed with preeclampsia were evaluated retrospectively. The patients were divided into two groups as early onset preeclampsia ( $\leq 34$ weeks) and late onset preeclampsia ( $>34$ weeks). Statistical analyses were used to compare demographic data, maternal risk factors and neonatal outcomes between the two groups.

Results: Out of 92 patients, 45 (49\%) were in the early onset preeclampsia and $47(51 \%)$ were in the late onset preeclampsia groups. Cesarean delivery and intrauterine growth retardation (IUGR) rates were significantly higher in the early onset preeclampsia group ( $p=0.01, p=0.025)$. High body mass index was an independent risk factor for late onset preeclampsia in the logistic regression analysis $(p=0.012)$. Neonatal morbidities and hospitalization rates in the neonatal intensive care unit (NICU) were significantly higher in the early onset preeclampsia group $(p<0.05$, $\mathrm{p}=0.005$, respectively). In addition, in the logistic regression analysis, it was found that early onset preeclampsia significantly increased the risks of IUGR (OR 2.96; 95\% CL: 1.12-7.81), being small for gestational age (OR 2.5; 95\% CL: 1.05-5.95), respiratory distress syndrome (OR 15.35; 95\% CL: 3.06-76.99), patent ductus arteriosus (OR 11.43; 95\% CL: 1.36-96.16) and hospitalization in the NICU (OR 2.48; 95\% CL: 1.06-5.77).

Conclusion: Early-onset preeclampsia was found to be an important risk factor for adverse neonatal outcomes while high body mass index during pregnancy was associated with late-onset preeclampsia.

Keywords: Early-onset, late-onset, preeclampsia, risk factors, neonatal outcomes öz

Amaç: Erken başlangıçlı ve geç başlangıçı preeklampside maternal risk faktörleri ve erken dönem neonatal sonuçların karşılaştırılması.

Gereç ve Yöntem: Hastanemizde preeklampsi tanısı almış hastalar retrospektif olarak değerlendirildi. Hastalar erken başlangıçlı preeklampsi ( $\leq 34$ hafta) ve geç başlangıçı preeklampsi (>34 hafta) olmak üzere 2 gruba ayrıldı. íki grup arasında demografik data, maternal risk faktörleri ve neonatal sonuçları karşılaşıırıak için istatistiksel analiz yapıldı. Bulgular: Preeklampsi tanısı alan 92 hastanın, 45 (\%49)'i erken başlangıçlı preeklampsi ve 47 (\%51)'si geç başlangıçlı preeklampsi idi. Erken başlangıçlı preeklampsi grubunda, sezaryen doğum ve intrauterin büyüme kısıtlılığı (IUBK) oranları anlamlı şekilde daha yüksek bulundu ( $p=0.01$, $\mathrm{p}=0.025$ ). Lojistik regresyon analizinde, gebelikte yüksek vücut kitle indeksinin geç başlangıçlı preeklampsi için bağımsız bir risk faktörü olduğu saptandı ( $p=0.012)$. Erken başlangıçlı preeklampsi grubunda, neonatal morbidite ve yenidoğan yoğun bakım ünitesine (YDYBÜ) yatış oranları anlamlı şekilde daha yüksek bulundu ( $p<0.05, p=0.005$, sırasıyla). Bunun yanında, lojistik regresyon analizinde erken başlangıçıı preeklampsinin, IUBK (OR 2.96; 95\% CL: 1.12-7.81), SGA (OR 2.5; 95\% CL: 1.05-5.95), respiratuar distres sendromu (OR 15.34; 95\% CL: 3.06-76.99), patent duktus arteriosus (OR 11.43; 95\% CL: 1.36-96.16) ve YDYBÜ'ne yatış (OR 2.48; 95\% CL: 1.06-5.77) riskini anlamlı şekilde artırdığı saptandı. Sonuç: Çalışmamızda, erken başlangıçlı preeklampsi, olumsuz neonatal sonuçlar için önemli bir risk faktörü olarak bulunurken, gebelikte yüksek vücut kitle indeksi geç başlangıçlı preeklampsi ile ilişkili bulundu.

Anahtar Kelimeler: Erken başlangıç, geç başlangıç, preeklampsi, risk faktörleri, neonatal sonuçlar

Corresponding Author/Sorumlu Yazar: Özgül Bulut E-mail: ozgulbulut@yahoo.com

Submitted/Başvuru: 13.10.2020 • Revision Requested/Revizyon Talebi: 28.10.2020 • Last Revision Received/Son Revizyon: 03.11.2020 •

Accepted/Kabul: 24.11.2020 


\section{INTRODUCTION}

Preeclampsia is a pregnancy-related multisystemic disorder seen after the $20^{\text {th }}$ week of pregnancy characterized by high blood pressure and proteinuria $(1,2)$. Preeclampsia affects 3-5\% of pregnancies worldwide and is the primary cause of maternal-fetal and neonatal mortality (3). If the symptoms of the disease are seen before the $34^{\text {th }}$ week of pregnancy, it is called early-onset preeclampsia (EOP); if manifestations present on or after the $34^{\text {th }}$ week of pregnancy, it is called late-onset preeclampsia (LOP) (2). Early- and late-onset preeclampsia are the consequences of different underlying pathophysiologic conditions. Placental defects, which are attributable to defective syncytiotrophoblast invasion and abnormal remodeling of the spiral arteries, are associated with early-onset disease. On the other hand, LOP usually occurs in the presence of maternal endothelial dysfunction, which is associated with more favorable neonatal outcomes than EOP. Briefly, EOP seems to be a placental disorder, whereas LOP is typically linked to maternal factors $(4,5)$. Although the diagnostic criteria are the same in these two different phenotypes of preeclampsia, different maternal and neonatal clinical and laboratory results were reported between EOP and $\operatorname{LOP}(6,7)$. While EOP is considered as a high risk for both mother and the fetus, LOP shows less severe clinical outcomes (7). Besides, there are still uncertainties about the maternal and fetal results of early and late-onset preeclampsia $(8,9)$. Therefore, in this study, we aimed to determine the maternal risk factors and early neonatal results between early- and lateonset preeclampsia.

\section{MATERIAL AND METHODS}

Mothers who gave birth at the Department of Obstetrics and Gynecology between January 2017-January 2019 and were diagnosed with preeclampsia (PE) were included in this retrospective cohort study. The study was approved by the Istanbul Medeniyet University Goztepe Training and Research Hospital's ethics committee (2020/0011).

PE was diagnosed as stated below-according to the report of American College of Obstetricians and Gynecologists: (i) after the $20^{\text {th }}$ gestational week, a recent onset hypertension (systolic blood pressure $\geq 140 \mathrm{mmHg}$ or diastolic blood pressure $\geq 90 \mathrm{mmHg}$ ) in a patient previously normotensive; and (ii) proteinuria ( $\geq 300 \mathrm{mg} / 24$ hours or dipstick $\geq 1$ ); or (iii) endorgan symptoms/findings (thrombocytopenia, altered serum creatinine level, increased liver transaminases, pulmonary edema, or cerebral or visual symptoms). Patients who were diagnosed with preeclampsia before the $34^{\text {th }}$ gestational week were classified as the EOP group, and those who were diagnosed on or after the $34^{\text {th }}$ gestational week were classified as the LOP group (2).

The demographic features, clinical findings, and laboratory data of the mothers and infants were obtained from the files of the Department of Obstetrics and Gynecology and Neonatal Intensive Care Unit (NICU). Maternal age, gravidity, parity, abortus, intrauterine death, intrauterine growth retardation
(IUGR), nulliparity, blood pressure measurements, body mass indices (BMI) before and during pregnancy, weight before and during pregnancy, PE history, PE hypertension history, smoking status, liver and kidney function tests, lactate dehydrogenase (LDH), albumin, and complete blood count results were recorded. Neonatal demographic features such as gestational age, birth weight, Apgar scores at the $1^{\text {st }}$ and $5^{\text {th }}$ minutes, sex, and the mode of delivery were recorded. Morbidities including respiratory distress syndrome (RDS), transient tachypnea of the newborn (TTN), patent ductus arteriosus (PDA), necrotizing enterocolitis (NEC), bronchopulmonary dysplasia (BPD), retinopathy of prematurity (ROP), intraventricular hemorrhage (IVH) and sepsis were added into the data. Additionally, history of NICU hospitalization, days of stay in NICU, mortality rate, and first postnatal-day neutrophil and thrombocyte counts and hemoglobin levels were also recorded. The gestational age was calculated using the last menstruation date and the crownrump length during the first trimester. Neonates with a birth weight less than the $10^{\text {th }}$ percentile were classified as small for gestational age (SGA). Pregnancies with chronic diseases, babies with congenital anomalies, and cases with incomplete medical data were excluded from the study.

\section{Statistical Analysis}

The statistical analyses of the data were performed with SPSS Statistics 22 (IBM SPSS, Turkey) software. By depending on the assumption that $60 \%$ of a difference between early and late-onset PE would be clinically significant, 5\% type I error (double-sided) and 45 women subjects with $80 \%$ power were estimated to be adequate. The descriptive values of the data were calculated as mean, \pm standard deviation, median [IQR], and number (\%). The compatibility of the data to normal distribution was assessed with the Kolmogorov Smirnov test. The changes in numeric features for the normally distributed data in terms of EOP and LOP groups were analyzed with student t-test; the ones who are not normally distributed were analyzed with the Mann Whitney-U test. Categorical variables in terms of both groups were analyzed with the Pearson Chi-Square test or Fisher Exact test. Logistic regression was conducted to estimate the relationship between maternal and pregnancy parameters and composite results. Maternal age, BMI, parity, nulliparity, pregestational weight, $\mathrm{PE}$ and hypertension history, aspartate aminotransferase (GOT), alanine transaminase (GPT), creatinine, platelet count, and LDH levels were included. Additionally, logistic regression analysis was carried out to assess the relationship between EOP and LOP and the neonatal outcomes. Statistical significance criteria were taken as $p<0.05$.

\section{RESULTS}

Out of the 92 patients included in our study, 45 (49\%) were diagnosed as EOP, while 47 (51\%) were diagnosed as LOP. In the EOP group, 23 (51\%) were mild PE, 22 (49\%) were severe PE. In the LOP group, 24 (51\%) were mild, 23 (49\%) were severe $P E$. In the EOP group, the data from 2 cases (an abortus and a stillbirth) were excluded from the study before analysis. The demographic features and laboratory findings of the mothers are shown in Table 1. In the EOP group, IUGR and cesarean 
rates were found to be significantly higher compared to the LOP group ( $p=0.025, p=0.01$, respectively). Other clinical features and laboratory findings were similar between the two groups. In the multiple logistic regression analysis to identify the risk factors in the EOP and LOP groups, it was found that high BMI during pregnancy was an independent risk factor for LOP (OR 1.362, 95\% CL: 1.070-1.732, $p=0.012$ ).

Upon analyzing the neonatal results in the EOP and LOP group, gestational age, birth weight, cord $\mathrm{pH}$, and Apgar scores at the $1^{\text {st }}$ and $5^{\text {th }}$ minutes were found to be significantly lower in the EOP group than those of the LOP group $(p=0.001, p=0.001$, $p=0.048, p=0.004, p=0.002$, respectively). Furthermore, in the EOP group, the incidence of SGA, RDS, PDA, NEC, and the rates of hospitalization in the NICU were significantly high ( $p=0.036, p=0.001, p=0.009, p=0.017, p=0.005$, respectively). Also, the days of stay in the NICU was significantly higher than the LOP group $(p=0.001)$. Neonatal mortality was not encountered in either group. In the hematologic assessment, the neutropenia and anemia rates in the EOP group were found to be significantly higher than the LOP group ( $p=0.003$, and $p=0.034$, respectively) (Table 2 ). In the logistic regression analysis, it was found that EOP significantly increases the risks of IUGR (OR 2.96; 95\% CL: 1.12-7.81), SGA (OR 2.50; 95\% CL: 1.05-5.95), RDS (OR 15.346; 95\% CL: 3.06-76.99), PDA (OR 11.43; 95\% CL: 1.36-96.16), and hospitalization in the NICU (OR 2.48; 95\% CL: 1.06-5.77) (Table 3).

\section{DISCUSSION}

Our results showed that early-onset preeclampsia had greater adverse effects on the infant than late-onset disease. In our study, gestational age and birth weight were found to be lower, and the SGA ratio was higher in the EOP group than the LOP group. Similarly, in previous studies, they reported that the gestational age and birth weight were found to be lower in the EOP group, while SGA and IUGR ratios were found higher than the LOP group $(10,11)$. It is well known that in preeclampsia, uteroplacental ischemia is one of the basic problems that affect the fetus and consequently the neonate. Severe placental failure causes intrauterine hypoxemia, thus,

Table 1: Baseline maternal characteristics and prenatal screening results according to the onset of preeclampsia.

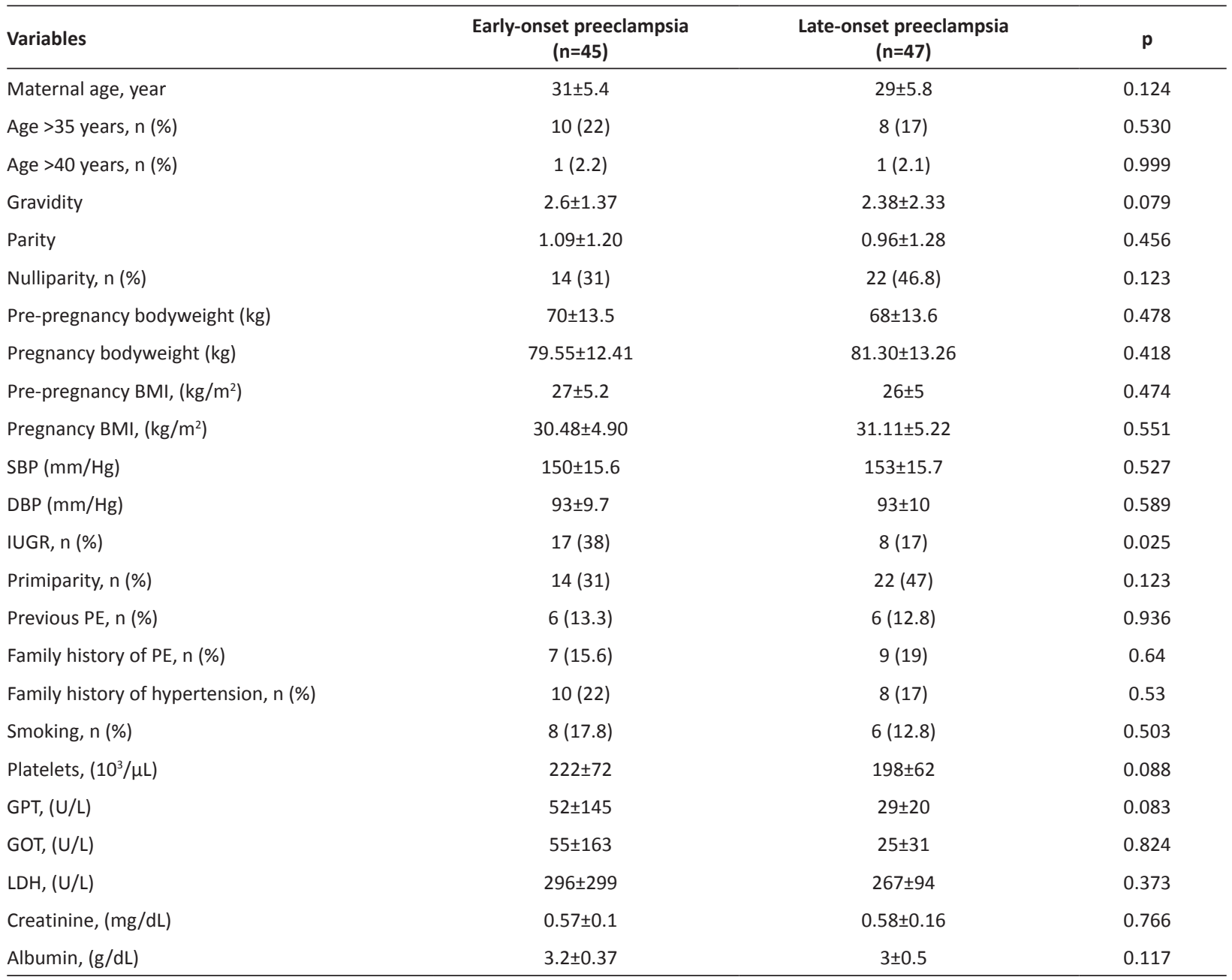

BMI: Body Mass Index, SBP: systolic blood pressure, DBP: Diastolic blood pressure, IUGR: Intrauterine growth retardation, PE: Preeclampsia, GOT: Aspartate aminotransferase, GPT: Alanine transaminase, LDH: Lactate dehydrogenase. Data were expressed as mean \pm SD, $p<0.05$ 
Table 2: Neonatal demographics and outcomes according to the onset of preeclampsia.

\begin{tabular}{|c|c|c|c|}
\hline Variables & $\begin{array}{l}\text { Early-onset preeclampsia } \\
\qquad(\mathrm{n}=45)\end{array}$ & $\begin{array}{l}\text { Late-onset preeclampsia } \\
\qquad(n=47)\end{array}$ & p \\
\hline Gestational age (weeks) & $34 \pm 4$ & $37.6 \pm 2.4$ & 0.001 \\
\hline Birth weight (g) & $1927 \pm 927$ & $2777 \pm 752$ & 0.001 \\
\hline Cesarean delivery, n (\%) & $37(82)$ & $27(57)$ & 0.01 \\
\hline Male, n (\%) & $21(46.7)$ & $18(38.3)$ & 0.417 \\
\hline Preterm delivery, n (\%) & $30(66.7)$ & $13(27.7)$ & 0.001 \\
\hline SGA n (\%) & $22(49)$ & $13(27.7)$ & 0.036 \\
\hline Cord $\mathrm{pH}$ & $7.29 \pm 0.10$ & $7.33 \pm 0.05$ & 0.048 \\
\hline 1- min Apgar score & $6 \pm 2.1$ & $7 \pm 1.7$ & 0.004 \\
\hline 5-min Apgar score & $8 \pm 1.2$ & $9 \pm 1.1$ & 0.002 \\
\hline RDS & $21(62)$ & $2(9.5)$ & 0.001 \\
\hline PDA & $12(36.4)$ & $1(4.8)$ & 0.009 \\
\hline NEK & $8(24.2)$ & $0(0.0)$ & 0.017 \\
\hline TTN & $6(18)$ & $7(33)$ & 0.183 \\
\hline ROP & $5(15.2)$ & $1(4.8)$ & 0.386 \\
\hline BPD & $8(24.2)$ & $1(4.8)$ & 0.075 \\
\hline IVK & $2(5.9)$ & $1(4.8)$ & 0.999 \\
\hline Sepsis & $4(12.1)$ & $3(14.3)$ & 0.999 \\
\hline Hospitalization, n (\%) & $33(73)$ & $21(45)$ & 0.005 \\
\hline Hospital stay (days) & $35 \pm 33$ & $7.8 \pm 6.4$ & 0.001 \\
\hline Hemoglobin, (g/dL) & $16.2 \pm 2.5$ & $17.9 \pm 2.9$ & 0.034 \\
\hline Neutrophils, $\left(10^{3} / \mu \mathrm{L}\right)$ & $3126 \pm 2449$ & $5988 \pm 3593$ & 0.003 \\
\hline Platelets, $\left(10^{3} / \mu \mathrm{L}\right)$ & $172393 \pm 91537$ & $204933 \pm 72815$ & 0.179 \\
\hline
\end{tabular}

SGA: Small for gestational age, RDS: Respiratory distress syndrome, PDA: Patent ductus arteriosus, NEC: Necrotizing enterocolitis, TTN: Transient tachypnea of newborn, ROP: Retinopathy of Prematurity, BPD: Bronchopulmonary dysplasia, IVH: Intraventricular hemorrhage. $p<0.05$

Table 3: Risk of Neonatal Morbidity in Early Onset vs Late Onset Preeclampsia.

\begin{tabular}{lc}
\hline & Risk ratio (95\% confidence interval) \\
\hline Neonatal outcomes & Early-onset PE vs Late-onset PE \\
\hline SGA & $2.5(1.05-5.95)$ \\
RDS & $15.4(3.1-76.99)$ \\
PDA & $11.429(1.36-96.16)$ \\
Hospitalization in NICU & $2.48(1,06-5,77)$ \\
\hline
\end{tabular}

SGA: Small for gestational age, RDS: Respiratory distress syndrome, PDA: Patent ductus arteriosus, NICU: Neonatal intensive care unit.

IUGR and premature birth might happen (12). Lisonkova et al. (13) reported a stronger association between early-onset disease and occurrence of SGA infant (as compared with lateonset disease and SGA), because of the profound effects of poor placental perfusion early in gestation and differences in disease severity. Moreover, in other studies, gestational age and birth weight were found to be lower in the EOP group than the LOP group, while no significant difference between the two groups was found in terms of SGA rates (14).
In our study, the RDS rate was found to be higher in the EOP group compared to the LOP group. No certain inference could be made about the RDS rate of the infants of preeclamptic mothers. In Soliman et.al.'s (15) study, which included late preterm babies, the RDS rate was found to be higher in the EOP group compared to normotensive cases and the LOP group. In Weitzner et.al.'s (11) study, no significant difference was found between the EOP and LOP groups. In preeclampsia, the stress hormones secreted by the fetus who encounters intrauterine stress might have an accelerating effect on fetal lung maturation; however, it is thought that RDS risk may be increased due to the damage to type II pneumocytes due to intrauterine hypoxemia caused by uteroplacental ischemia (16). Moreover, in RDS pathophysiology, an increase in the levels of antiangiogenic factors, like soluble vascular endothelial growth factor receptor 1 (sFlt-1) and soluble Endoglin, and a decrease in the levels of angiogenic factors, like vascular endothelial growth factor (VEGF) and placental growth factors may play an important role in increasing the risk of RDS $(17,18)$. In an animal test, VEGF was found to increase alveolar growth and surfactant level (18).

In our study, the NEC rate was found to be significantly higher in the EOP group than the LOP group. When the NEC rates of 
infants of EOP and LOP mothers were assessed, some studies showed NEC rates were higher in infants of EOP mothers $(6,7)$, whereas other studies demonstrated no relationship between the infants of EOP and LOP mothers (10). In preeclampsia, the risk of NEC is thought to increase due to both fetal hypoxemia based on insufficient placental blood flow and reduction in blood flow to the gastrointestinal system due to the reorganization of fetal blood flow due to hypoxemia (19). The VEGF is also thought to influence NEC pathology (20).

Another finding in our study showed that the PDA rate was higher in the EOP group. There have been very few studies researching the frequency of PDA in infants of preeclamptic mothers. Withagen et. al.'s (21) study reported that the PDA rate was increased in the infants of preeclamptic mothers. Shah et.al.'s (22) study found that in 26-33 weeks infants of preeclamptic mothers, PDA rates were decreased. It is known that transforming growth factor- $\beta$ and VEGF are effective in anatomical closure of PDA (23).

In our study, anemia was found to be higher in infants of EOP mothers. Similar to our findings, Ni et al.'s (7) study found that the rate of anemia was significantly higher in the infants of EOP mothers. Anemia is the most common hematological problem in premature infants. Hemoconcentration and hyperviscosity are expected in IUGR, but anemia was also observed in severe IUGR infants. This is explained by the development of resistance against erythropoietin (EPO) due to the long-lasting high concentration of EPO due to severe placental failure (24).

In our study, another abnormal hematological finding was the significantly lower number of neutrophils in the EOP group than the LOP group. In both premature and IUGR infants, neutropenia is a commonly seen finding. The etiology of neutropenia seen in about half of the infants of the mothers' hypertension is still unknown. A decrease in production, further clinical deterioration of the infant (related to infection, alloimmunization, and isoimmunization), and an increase in microvascular endosteal neutrophil migration are seen to be the most responsible causes. Neutropenia is thought to be associated with placenta-derived inhibitors or the effect of EPO on neutrophil precursors (25).

We think that the cause of high morbidity in the infants of EOP mothers is the high rate of IUGR and prematurity in this group. In addition, compared to LOP, the high sFlt-1 levels and low VEGF levels play a role in the pathogenesis of EOP. Antiangiogenic conditions become more apparent exposing the fetus to the intrauterine antiangiogenic environment for a longer period. All these factors contributed to the increase in neonatal morbidity in infants of EOP mothers and increased hospitalization in the NICU.

Previous studies reported that the classical risk factors for preeclampsia are previously existing medical conditions such as nulliparity, old maternal age, previous preeclampsia history, high BMI, gestational diabetes, multiple pregnancies, assisted reproduction, and chronic hypertension (5). Chronic hypertension was found to be associated with PE in EOP
$(26,27)$; young maternal age, nulliparity, and high BMI were found to be associated with LOP (13). In our study, no significant difference was found between the EOP and LOP groups in terms of clinical and laboratory features. Besides, in multiple logistic regression analyses, a linear relationship was identified between high BMI and LOP. Being overweight and obesity have a two-three-fold increase in the risk of PE. Additionally, being overweight and obesity are highly prevalent worldwide, and thus, cumulatively account for over 40 percent of PE cases $(28,29)$. In a systematic review of 13 cohort studies comprising nearly 1.4 million women, the risk of preeclampsia doubled with each $5-7 \mathrm{~kg} / \mathrm{m}^{2}$ increase in pre-pregnancy BMI (30). However, similar studies investigating EOP and LOP, being overweight/obesity were found to increase LOP risk, but not EOP (31). The mechanisms underlying the relationship between preeclampsia and obesity are not completely understood and have only been partially explored. Increased cytokine-mediated inflammation and oxidative stress, increased shear stress, dyslipidemia, and increased sympathetic activity have all been proposed as possible pathways (5).

This study has notable strengths. Our study has an adequate sample size. Additionally, our study includes detailed information, including the sociodemographic and clinical characteristics of the participants. There are, however, limitations of our research. The basic limitations of our study were the retrospective design of our study and missing data. Finally, the EOP and LOP groups were not compared with a control group composed of normotensive mothers.

Early-onset preeclampsia had greater adverse effects on the infant than late-onset disease. Our study also revealed that high BMI was a stronger risk factor for late-onset than for early-onset disease. Therefore, improved pre- and postnatal management of early-onset preeclamptic pregnant women who are planning to deliver in hospitals with high-level NICUs should be emphasized to provide adequate treatment and follow-up against possible neonatal morbidities. Close followup of these infants against morbidities that might occur postdelivery will positively affect the prognosis of these infants.

Etik Komite Onayı: Bu çalışma için etik kurul onayı İstanbul Medeniyet Üniversitesi Göztepe Eğitim ve Araştrrma Hastanesi Etik Kurulu'ndan alınmıştır (2020/0011).

Hakem Değerlendirmesi: Dış bağımsız.

Yazar Katkıları: Çalışma Konsepti/Tasarım- Ö.B., M.H., S.D., N.B., A.T., F.O.; Veri Toplama- Ö.B., M.H., S.D.; Veri Analizi/Yorumlama- Ö.B., M.H., S.D., N.B., A.T., F.O.; Yazı Taslağı- Ö.B., M.H., S.D., N.B.; Iç̧eriğin Eleştirel İncelemesi- A.T., F.O.; Son Onay ve Sorumluluk- Ö.B., M.H., S.D., N.B., A.T., F.O.; Malzeme ve Teknik Destek- Ö.B., M.H., S.D., N.B. Süpervizyon- A.T., F.O.

Çıkar Çatışması: Yazarlar çıkar çatışması beyan etmemişlerdir.

Finansal Destek: Yazarlar finansal destek beyan etmemişlerdir. 
Ethics Committee Approval: This study was approved by the Istanbul Medeniyet University Goztepe Training and Research Hospital's ethics committee (2020/0011).

Peer Review: Externally peer-reviewed.

Author Contributions: Conception/Design of Study- Ö.B., M.H., S.D., N.B., A.T., F.O.; Data Acquisition- Ö.B., M.H., S.D.;Data Analysis/ Interpretation- Ö.B., M.H., S.D., N.B., A.T., F.O.; Drafting ManuscriptÖ.B., M.H., S.D., N.B.; Critical Revision of Manuscript- A.T., F.O.; Final Approval and Accountability- Ö.B., M.H., S.D., N.B., A.T., F.O.; Technical or Material Support- Ö.B., M.H., S.D., N.B.; Supervision- A.T., F.O.

Conflict of Interest: Authors declared no conflict of interest.

Financial Disclosure: Authors declared no financial support.

\section{REFERENCES}

1. Monteith C, Egan K, O'Connor H, Maguire P, Kevane B, Szklanna $\mathrm{PB}$, et al. Early-onset preeclampsia is associated with an elevated mean platelet volume (MPV) and a greater rise in MPV from time of booking compared with pregnant controls: results of the CAPE study. J Perinat Med 2018;46(9):1010-15. https://doi.org/ 10.1515/ jpm-2017-0188.

2. American College of Obstetricians and Gynecologists. Practice Bulletin No. 202: gestational hypertension and preeclampsia. Obstet Gynecol 2019;133(1):1-25. https://doi.org/10.1097/AOG.0000000000003018.

3. Machado JSR, Machado MSR, Bertagnolli TV, Martins LAB, Freitas SF, Ovidio PP, et al. Role of plasma PIGF, PDGF-AA, ANG-1, ANG2, and the ANG-1/ANG-2 ratio as predictors of preeclampsia in a cohort of pregnant women. Pregnancy Hypertens 2019;16:105111. https://doi:10.1016/j.preghy.2019.03.011.

4. Staff AC. The two-stage placental model of preeclampsia: An update. J Reprod Immunol 2019;134-135:1-10. https:// doi:10.1016/j.jri.2019.07.00.

5. Burton GJ, Redman CW, Roberts JM, Moffett A. Pre-eclampsia: pathophysiology and clinical implications. BMJ 2019;366:12381. https://doi.org/10.1136/bmj.I2381.

6. Kucukbas GN, Sanhal CY, Uygur D. Plasma endocan levels in early and late-onset preeclampsia. Fetal Pediatr Pathol 2019;1-8. https://doi.org/10.1080/15513815.2019.1693674.

7. Ni Y, Cheng W. Comparison of indications of pregnancy termination and prognosis of mothers and neonates in early- and late-onset preeclampsia. Hypertens Pregnancy 2016; 35(3): 315-22. https:// doi.org/10.3109/10641955.2016.1143486.

8. Publications Committee, Society for Maternal-Fetal Medicine, Sibai BM. Evaluation and management of severe preeclampsia before 34 weeks' gestation. Am J Obstet Gynecol 2011;205(3):191-198. https://doi.org/10.1016/j.ajog.2011.07.017.

9. Pettit F, Mangos G, Davis G, Henry A, Brown MA. Pre-eclampsia causes adverse maternal outcomes across the gestational spectrum. Pregnancy Hypertens 2015;5(2):198-204. https://doi. org/10.1016/j.preghy.2015.02.002

10. Wójtowicz A, Zembala-Szczerba M, Babczyk D, KołodziejczykPietruszka M, Lewaczyńska O, Huras H.et al. Early- and late-onset preeclampsia: a comprehensive cohort study of laboratory and clinical findings according to the New ISHHP Criteria. Int J Hypertens 2019;2019:4108271. https://doi.org/10.1155/2019/4108271.
11. Weitzner O, Yagur Y, Weissbach T, Man El G, Biron-Shental T. Preeclampsia: risk factors and neonatal outcomes associated with early- versus late-onset diseases. J Matern Fetal Neonatal Med 2020;33(5):780-84. https://doi.org/10.1080/14767058.2018.150 0551.

12. Gruslin A, Lemyre B. Pre-eclampsia: fetal assessment and neonatal outcomes. Best Pract Res Clin Obstet Gynaecol 2011;25(4):491507. https://doi.org/10.1016/j.bpobgyn.2011.02.004.

13. Lisonkova S, Joseph KS. Incidence of preeclampsia: risk factors and outcomes associated with early- versus late-onset disease. 2013;209(6):544.e1-544.e12. https://doi:10.1016/j. ajog.2013.08.019

14. Madazli R, Yuksel MA, Imamoglu M, et al. Comparison of clinical and perinatal outcomes in early- and late-onset preeclampsia. Arch Gynecol Obstet 2014;290(1):53-57. https://doi.org/10.1007/ s00404-014-3176-x.

15. Soliman Y, Alshaikh B, Alawad E, Akierman A, Elsharkawy A, Yusuf K. Respiratory outcomes of late preterm infants of mothers with early and late-onset preeclampsia. J Perinatol 2020;40(1):39-45. https://doi.org/10.1038/s41372-019-0497-4.

16. Orgeig S, Crittenden TA, Marchant C, McMillen IC, Morrison $\mathrm{JL}$. Intrauterine growth restriction delays surfactant protein maturation in the sheep fetus. Am J Physiol Lung Cell Mol Physiol 2010;298(4):575-83. https://doi.org/10.1152/ajplung.00226.2009.

17. Chaiworapongsa $T$, Chaemsaithong $P$, Yeo L, Romero R. Preeclampsia part 1: current understanding of its pathophysiology. Nat Rev Nephrol 2014;10(8):466-80. https://doi.org/10.1038/ nrneph.2014.102.

18. Wang A, Holston AM, Yu KF, Zhang J, Toporsian M, Karumanchi $\mathrm{SA}$, et al. Circulating anti-angiogenic factors during hypertensive pregnancy and increased risk of respiratory distress syndrome in preterm neonates. J Matern Fetal Neonatal Med 2012;25(8):144752. https://doi.org/10.3109/14767058.2011.640368.

19. Simchen MJ, Beiner ME, Strauss-Liviathan N, Dulitzky M, Kuint J, Mashiach S, et al. Neonatal outcome in growth-restricted versus appropriately grown preterm infants. Am J Perinatol 2000;17(4):187-92. https://doi.org/10.1055/s-2000-9423.

20. Bányász I, Bokodi G, Vásárhelyi B, Treszl A, Derzbach L, Szabó A, et al. Genetic polymorphisms for vascular endothelial growth factor in perinatal complications. Eur Cytokine Netw 2006;17:266-70. https://doi.org/10.1684/ecn.2006.0041.

21. Withagen MI, Visser W, Wallenburg HC. Neonatal outcome of temporizing treatment in early-onset preeclampsia. Eur J Obstet Gynecol Reprod Biol 2001;94(2):211-5. https://doi.org/10.1016/ s0301-2115(00)00332-8.

22. Shah DM, Shenai JP, Vaughn WK. Neonatal outcome of premature infants of mothers with preeclampsia. J Perinatol 1995;15(4):264-7.

23. Hamrick SE, Hansmann G. Patent ductus arteriosus of the preterm infant. Pediatrics 2010;125(5):1020-30. https://doi.org/10.1542/ peds.2009-3506

24. Teramo KA, Widness JA. Increased fetal plasma and amniotic fluid erythropoietin concentrations: markers of intrauterine hypoxia. Neonatology 2009;95(2):105-16. https://doi.org/10.1159/000153094.

25. Park YH, Lee GM, Yoon JM, Cheon EJ, Ko KO, Lee YH, et al. Effect of early postnatal neutropenia in very low birth weight infants born to mothers with pregnancy-induced hypertension. Korean J Pediatr 2012;55(12):462-9. https://doi.org/10.3345/kjp.2012.55.12.462. 
26. Akbar AMI, Herdiyantini M, Aryananda RA, Clninta N, Wardhana MP, Gumilar KE, et al. Serum heme oxygenase 1 (HO-1), soluble FMS like tyrosine kinase (sFlt-1) level, and neonatal outcome in early-onset, late-onset preeclampsia, and normal pregnancy. Hypertens Pregnancy 2018;37(4):175-81. https://doi.org/10.10 80/10641955.2018.1494187.

27. Kucukgoz GU, Ozgunen FT, Buyukkurt S, Guzel AB, Urunsak IF, Demir SC, et al. Comparison of clinical and laboratory findings in early- and late-onset preeclampsia. J Matern Fetal Neonatal Med 2013;26(12):1228-33. https://doi.org/10.3109/14767058.2013.7 76533.

28. Poorolajal J, Jenabi E. The association between body mass index and preeclampsia: a meta-analysis. J Matern Fetal Neonatal Med 2016;29(22):3670-6. https://doi.org/10.3109/14767058.2016.11 40738 .
29. Roberts JM, Redman CWG, Global Pregnancy Collaboration. Global Pregnancy Collaboration symposium: prepregnancy and very early pregnancy antecedents of adverse pregnancy outcomes: overview and recommendations. Placenta 2017;60:103-109. https://doi. org/10.1016/j.placenta.2017.07.012.

30. O'Brien TE, Ray JG, Chan WS. Maternal body mass index and the risk of preeclampsia: a systematic overview. Epidemiology 2003;14(3):368-74. https://doi.org/10.1097/00001648200305000-00020

31. Ornaghi S, Tyurmorezova A, Algeri P, Giardini V, Ceruti P, Vertemati $E$, et al. Influencing factors for late-onset preeclampsia. J Matern Fetal Neonatal Med 2013;26(13):1299-302. https://doi.org/10.31 09/14767058.2013.783807. 